\title{
Swiss reject curbs on genetic engineering
}

[MUNICH] Proposals to severely restrict genetic engineering in Switzerland - for example by banning the use of transgenic animals in research and halting field trials with transgenic crops - were rejected in a referendum last Sunday (7 June) by a surprisingly strong majority.

Two-thirds of the voters rejected restrictions proposed in 1992 by 70 pressure groups opposed to biotechnology, bringing to an end months of bitter - and expensive campaigning by both sides. The turnout of just over 40 per cent was particularly high for Switzerland, under whose system of government the electorate is frequently asked to vote on relatively minor legislative matters.

More than 80 per cent of the French- and Italian-speaking parts of the country voted 'no' in the referendum. But the 'no' vote was also higher than expected in German-speaking areas, where the population is more mistrustful of genetic engineering. The referendum's proposals were rejected in all of Switzerland's 26 cantons.

Most recent surveys had indicated that the vote would be very close and could swing either way (see Nature 393, 405; 1998). "We were sitting in our department all Sunday afternoon, listening to the radio and biting our nails," says Sebastian Brandner, an assistant professor at the Institute for Neuropathology at the University of Zürich. "When the result became clear, the relief among all colleagues was palpable."

Many believe that the willingness of prominent scientists to write popular newspaper columns and appear on television contributed to the clear 'no' vote. Those who had put themselves in the media spotlight included the Nobel laureate Rolf Zinkernagel, head of immunology at the University of Zürich, and Adriano Aguzzi, head of neuropathology at the university.

Politicians and researchers had warned that restrictions on genetic engineering would seriously harm the Swiss economy, and could cause the loss of tens of thousands of jobs in academic and industrial research departments.

The Swiss government will now continue with an initiative of its own called 'Gen-Lex', launched last year, which was intended in part to encourage waiverers to vote 'no' in the referendum by tightening and coordinating existing regulations on genetic engineering (see Nature 391, 312; 1998).

The Gen-Lex initiative has broad support, including backing from industry. It includes, for example, a proposed adaptation of the animal protection law to ban the breeding of transgenic farm animals that might suffer pain.

It also proposes to extend the liability period for all genetic engineering activities, which is 20 years in the European Union, to 30 years in Switzerland. This means that a company or a research institute will be liable to pay for damage caused by a genetically engineered organism for up to 30 years after its first approved release into the environment.

These rules will come into effect in 1999 at the earliest. But a national ethics committee - another Gen-Lex initiative - has already been set up as a permanent advisory body for the government. This committee of 12 experts in science, ethics and law, advises on all ethical issues pertinent to the use of animals in genetics research.

The committee will also serve as an "institutionalized dialogue platform between experts, the government and the public," according to Conrad Engler, head of gene technology at Interpharma, the association of the Swiss pharmaceutical industry.

Researchers recognize lack of dialogue as one reason for public scepticism about biotechnology.

\section{India boosts budget for atomic research in wake of bomb tests}

[NEW DELHI] India, which carried out nuclear tests and subsequently declared itself a nuclear weapons state last month, has increased the budget of its Department of Atomic Energy (DAE) by 30 per cent. The rise is the first major hike in the department's 50-year history.

But officials are still insisting that the enhanced funding, which takes the department's budget to US $\$ 652$ million, is intended to lead to the generation of more electricity by nuclear power, rather than to building improved nuclear bombs.

Overall, the 1998-99 budget presented to the country's parliament last week allocates $\$ 2,443$ million for non-capital spending on science and technology, 22 per cent more than last year. Expenditure on space will rise by 52 per cent, to $\$ 401$ million.

The allocation for defence research has gone up by 24 per cent, to $\$ 619$ million. The move has inevitably raised speculation that the Bharatiya Janata Party (BJP) has decided to maintain the momentum of the nuclear blast by strengthening all the three strategic departments associated with nuclear weapons.

But Rajagopalan Chidambaram, DAE secretary and a key scientist in the nuclear testing, denies this. "The decision on budget allocation was taken well before the Pokhran

\begin{tabular}{|c|c|c|}
\hline \multicolumn{3}{|c|}{$\begin{array}{l}\text { Budget allocation 1998-99 (in millions of US } \\
\text { dollars) for capital plus non-capital spending }\end{array}$} \\
\hline Area & Amount & $\begin{array}{l}\text { Percentage } \\
\text { increase 98/99 }\end{array}$ \\
\hline Atomic energy & 652 & $30.4 \%$ \\
\hline Space & 401 & $51.9 \%$ \\
\hline Defence research & 619 & $24 \%$ \\
\hline Agricultural research & 252 & $58 \%$ \\
\hline Environmental science & 205 & $51.9 \%$ \\
\hline Industrial research & 160 & $6 \%$ \\
\hline Science and technology & 156 & $2 \%$ \\
\hline Medical research & 129 & $19.4 \%$ \\
\hline Non-conventional energy & 102 & $108.2 \%$ \\
\hline Electronics & 53 & $29.2 \%$ \\
\hline Biotechnology & 29 & $20.8 \%$ \\
\hline Oceanography & 27 & $3.8 \%$ \\
\hline Total & 2,785 & \\
\hline
\end{tabular}

tests," he says. "The main increase is in the plan allocation for nuclear power."

Chidambaram points out that, while

DAE's research facilities receive only a 40 per cent boost in funding, the nuclear power schemes get an 86 per cent rise. "The government is very keen to encourage the power sector," he says.

Krishnagopala Iyengar, the former head of DAE, describes the Indian weapons programme as a low-cost affair. He says work related to the nuclear bomb over many years did not even have a regular budget, and was a "part-time" job for DAE scientists. Plutonium was a by-product of the nuclear energy programme and, according to Iyengar, the five bombs tested by India cost just \$1.25 million to fabricate.

DAE plans to use the enhanced funding for the development of intense particle beams for research, and for an advanced heavy-water reactor to burn thorium abundant in India.

A spokesman for the BJP government said that much of the new space budget is intended to build the next-generation INSAT-3 telecommunication satellites, which will replace the INSAT-2E series.

Rocket development also gets a significant share, and officials say the objective is to develop the Geostationary Launch Vehicle for the INSAT-3 satellites. The budget provides $\$ 12.5$ million for a new launch pad for the vehicle.

The research community in general has welcomed the extra funding for science. Spending on education has increased by 50 per cent to $\$ 1,762$ million, and $\$ 6.25$ million has been set aside for improving research infrastructure in universities. "This is the first time a new initiative has been taken to rebuild science and engineering departments in universities," says Valangiman Ramamurthy, secretary in the science ministry.

K.S. Jayaraman 